\title{
Badania ultradźwiękowe płyt włóknisto-cementowych
}

\section{Ultrasonic testing of fibre-cement boards}

\section{Streszczenie}

W artykule przedstawiona została możliwość lokalizacji delaminacji w płycie włóknisto-cementowej za pomocą specjalnie do tego celu skonstruowanego urządzenia wykorzystującego metodę ultradźwiękową i fale podłużne. Przeprowadzono badania na trzech rodzajach płyt. Stwierdzono, że proponowana metoda diagnostyczna umożliwia wykrywanie lokalnych nieciągłości, np. obszarów o obniżonej zwartości, czy delaminacji w płytach włóknisto-cementowych na obszarze średnicy wiązki metodą estymacji prędkości fali ultradźwiękowej. Zaletami metody są niewielkie wymiary urządzenia i krótki czas badania.

Słowa kluczowe: płyty włóknisto-cementowe; badania nieniszczące; ultradźwięki

\section{Abstract}

This article presents the possibility of delamination location in the fiber-cement board using a specially-designed device operating on the principle of ultrasonic method and measuring of longitudinal waves velocity. Studies were carried out on three types of board. It was found that the proposed diagnostic method allows detection of local discontinuities, eg. the areas of reduced compactness, or delamination in fiber-cement boards in the area of the beam diameter by an estimation velocity of ultrasonic waves. The advantages of the method are: small dimensions of the device and short duration of the study.

Keywords: fibre-cement boards; nondestructive evaluation; ultrasonic

\section{Wstęp}

Projektowane obecnie elewacje budynków charakteryzują się atrakcyjnym wyglądem i podwyższona odpornością na degradujące czynniki atmosferyczne. Na rynku materiałów budowlanych znajduje się wiele materiałów i inwestor często staje przed problemem jaki materiał wybrać do realizacji swojej inwestycji, w tym również elewacji. Korzysta on wówczas najczęściej z podpowiedzi architekta. W architekturze można zaobserwować obecnie trend, w którym bardzo popularne staje się wykonywanie elewacji w postaci tzw. elewacji wentylowanej z zastosowaniem różnego rodzaju okładzin, a w szczególności okładzin z płyt włóknistocementowych. Jest to materiał obecnie często stosowany. Przykładową tego typu elewację pokazano na rysunku 1.

Historia związana z płytami włóknisto-cementowymi sięga już ponad 115 lat i związana jest z czeskim inżynierem Ludwikiem Hatschekiem, który to opatentował materiał budowlany pod nazwą „eternit” [1,2]. Materiał ten zawierał wówczas włókna azbestowe, które dzisiaj stały się materiałem niedozwolonym do stosowania i zastąpione je włóknami celulozowymi $[1,2]$. Płyty wytwarzane z zastosowaniem tych włókien zawierają ponadto ok. 55\%-65\% cementu, a pozostałą część stanowią wypełniacze (najczęściej mączka wapienna) oraz dodatki i domieszki. Wytwarzany z takich składników materiał zyskał na popularności ze względu na swoja dużą trwałości i wytrzymałość na zginanie oraz odpornością na wilgoć i korozję biologiczną [1 $\div 3]$.

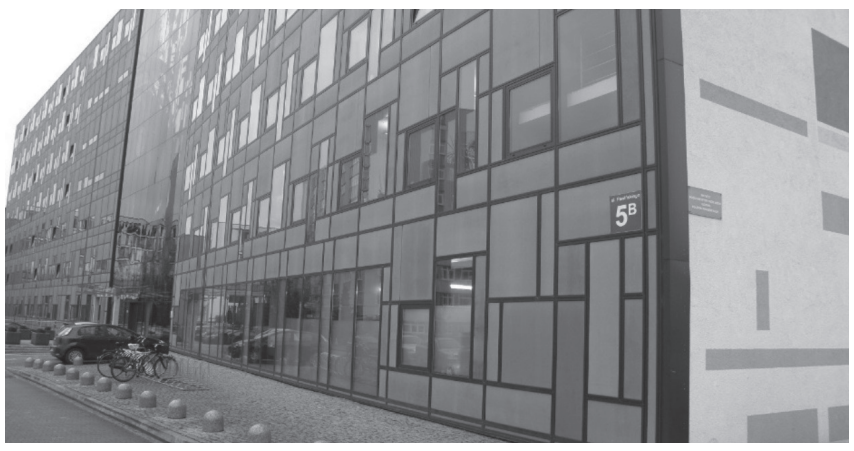

Rys. 1. Widok fragmentu budynku z elewacją wentylowaną Fig. 1. Partial view of the building with ventilated facade

Jak każdy wyrób budowlany płyty włóknisto-cementowe muszą posiadać odpowiednie dopuszczenia umożliwiające ich zastosowanie w budownictwie. Elementem takiego dopuszczenia są odpowiednie badania, związane przede wszystkim z kontrolą jakości płyt w trakcie ich produkcji. Kontrola ta oparta jest głównie na badaniach wizualnych dotyczących powierzchni płyty. Brakuje jednak metod badawczych umożliwiających pozyskanie informacji o strukturze wewnętrznej materiału, szczególnie jeżeli chodzi o delaminacje (rozwarstwienie) płyty, bo wada ta ma istotny wpływ między innymi na

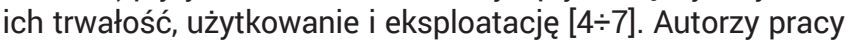
zaproponowali do takiego badania wykorzystanie nieniszczącej metody ultradźwiękowej z zastosowaniem do tego celu zbudowanego urządzenia wykorzystującego fale podłużne.

mgr inż. Tomasz Dębowski; dr inż. Marcin Lewandowski; dr inż. Sławomir Mackiewicz; dr hab. inż. Zbigniew Ranachowski, prof. IPPT PAN - Instytut Podstawowych Problemów Techniki Polskiej Akademii Nauk w Warszawie; dr hab. inż. Krzysztof Schabowicz - Politechnika Wrocławska.

Autor korespondencyjny/Corresponding author: k.schabowicz@pwr.edu.pl 


\section{Opis metody badawczej}

Na rysunku 2 pokazano zbudowaną do badania delaminacji płyt włóknisto-cementowych aparaturę ultradźwiękową wykorzystującą fale podłużne. Zasadniczą jej częścią jest uchwyt z zamocowanymi głowicami ultradźwiękowymi. Zastosowano głowice typu Omniscan firmy Panametrics o częstotliwości rezonansowej $1 \mathrm{MHz}$ i średnicy $19 \mathrm{~mm}$.
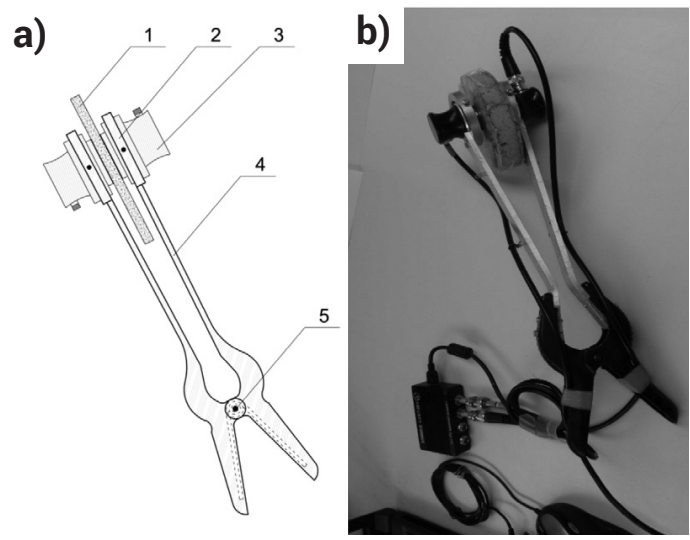

Rys. 2. Urządzenie ultradźwiękowe do badania delemaniacji płyt włóknisto-cementowych: a) schemat urządzenia, b) widok urządzenia; 1 - płyta włóknisto-cementowa, 2 - przeguby uchwytu, 3 - głowice ultradźwiękowe, 4- sztywne wysięgniki umożliwiających dokonywanie pomiaru na całej powierzchni badanej płyty, 5 - sprężynowy mechanizm dociskowy umieszczony wewnątrz uchwytów Fig. 2. Ultrasound device for fiber-cement boards delamination testing: a) schematic diagram, b) view of the device; 1 - fiber-cement board, 2 - joints grabs, 3 - ultrasound heads, 4 - rigid booms allow to measure the entire area of the test plate, 5 - spring-loaded clamping mechanism placed inside the brackets

Sposób wykrywania delaminacji w płytach włókno-cementowych polega na pomiarze lokalnych zmian prędkości podłużnej fali ultradźwiękowej i porównania ich z prędkością podłużnej fali ultradźwiękowej we wzorcowej próbce badanego materiału pozbawionej delaminacji. Prędkość podłużną fali ultradźwiękowej wyznacza się stosując zamocowaną w elemencie pozycjonującym parę głowic ultradźwiękowych o średnicy wiązki ultradźwiękowej nie przekraczającej $20 \mathrm{~mm}$, zapewniającym pewne i powtarzalne sprzężenie z badanym obiektem. Sygnał elektryczny z głowic nadawczej i odbiorczej, umieszczonych po obu stronach badanej płyty włóknisto-cementowej jest przesyłany do cyfrowego defektoskopu ultradźwiękowego umożliwiającego określenie odstępu czasu pomiędzy pierwszym a drugim echem docierającym do głowicy odbiorczej. Prędkość podłużnej fali ultradźwiękowej $v_{L}$ jest wyznaczana ze wzoru (1):

$$
v_{L}=2 g /\left(t_{2}-t_{1}\right)+c
$$

gdzie: $t_{1}$ i $t_{2}$ oznaczają opóźnienia czasu rejestracji pierwszego i drugiego echa docierającego do głowicy odbiorczej, mierzone w mikrosekundach względem początku impulsu nadawczego, $g$ oznacza grubość płyty włókno-cementowej, a c oznacza poprawkę wyznaczaną na podstawie pomiaru prędkości fali ultradźwiękowej wykonanej na znormalizowanym wzorcu o znanej grubości i prędkości fali ultradźwiękowej.

Rozdzielczość w dziedzinie czasu zastosowanego defektoskopu cyfrowego wynosi $10 \mathrm{~ns}$.

Głowice umieszczone są w ruchomych przegubach umożliwiających docisk głowic do badanej płyty włóknisto-cementowej równomiernie na całych powierzchniach czołowych. Dodatkowo uchwyt jest wyposażony w sprężynę umożliwiającą pewny docisk głowic do powierzchni badanych płyt. Przed procesem wykrywania delaminacji powierzchnię płyty włóknisto-cementowej zabezpiecza się przezroczystą folią samoprzylepną, a powierzchnie czołowe ultradźwiękowych głowic nadawczej i odbiorczej pokrywa cienką warstwą gęstego żelu silikonowego.

Rozwiązanie takie umożliwia wykrywanie delaminacji o długości powyżej $10 \mathrm{~mm}$ w płytach włóknisto-cementowych o grubości w zakresie $4 \div 40 \mathrm{~mm}$. Ponadto proces wykrywania delaminacji jest wykonywany w sposób nie naruszający struktury badanego obiektu, pomiar prędkości fali ultradźwiękowej jest w sposób zautomatyzowany i w czasie nie przekraczającym jednej sekundy.

\section{Przykładowe badania}

Badania eksperymentalne przeprowadzone przy wykorzystaniu zbudowanego urządzenia ultradźwiękowego. Głównym celem badań było poszukiwanie imperfekcji w materiale płyty na podstawie analizy prędkości podłużnej fali ultradźwiękowej. Pojawienie się wady w materiale charakteryzowało się obserwowaną skokową zmianą tej prędkości. W tablicy I przedstawiono rodzaje płyt włóknisto-cementowych wykorzystanych do badań. Natomiast na rysunku 3 pokazano przykładowe badanie przy wykorzystaniu zbudowanego urządzenia ultradźwiękowego.

W tablicy II zebrano parametry otrzymane z badań płyt włóknisto-cementowych w tym wytrzymałość na zginanie i prędkość podłużnej fali ultradźwiękowej. Natomiast

Tablica I. Rodzaje płyt włóknisto-cementowych wykorzystanych do badań

Table I. Types of fiber cement boards used for tests

\begin{tabular}{|c|c|c|c|}
\hline Oznaczenie płyty & A & B & C \\
\hline Rodzaj płyty & $\begin{array}{c}\text { włóknisto-cementowa } \\
\text { barwiona w masie }\end{array}$ & włóknisto-cementowa & włóknisto-cementowa \\
\hline Grubość płyty [mm] & 8 & 8 & 10 \\
\hline Gęstość objętościowa $\left[\mathbf{k g} / \mathbf{m}^{3}\right]$ & 1200 & & 1000 \\
\hline Widok płyty & & & \\
\hline
\end{tabular}


na rysunku 4 przedstawiono zależność prędkości fali ultradźwiękowej w funkcji gęstości objętościowej badanej płyty włóknisto-cementowej. Na wykresie zaznaczono 5\% zakresy niepewności mierzonych wielkości i krzywą regresji. Należy w tym miejscu wyjaśnić, że prędkość fali ultradźwiękowej nie zależy od wytrzymałości na zginanie płyt. Ma na nią jednak wpływ gęstość objętościowa płyt.

Tablica II. Parametry otrzymane z badań płyt włóknisto-cementowych Table II. The parameters obtained with fiber cement boards

\begin{tabular}{|c|c|c|c|}
\hline Oznaczenie płyty & A & B & C \\
\hline $\begin{array}{c}\text { Wytrzymałość } \\
\text { na zginanie [MPa] }\end{array}$ & 13,98 & 9,45 & 9,34 \\
\hline $\begin{array}{c}\text { Prędkość podłużnej fali } \\
\text { ultradźwiękowej [km/s] }\end{array}$ & 2,20 & 1,15 & 2,69 \\
\hline
\end{tabular}

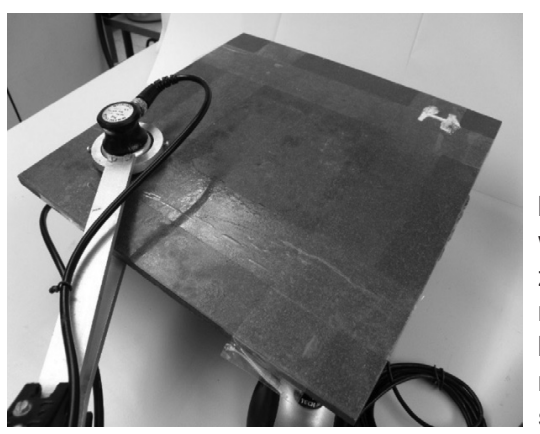

Rys. 3. Badanie płyty włóknisto-cementowej zbudowanym urządzeniem ultradźwiękowym Fig. 3. Test of fiber-cement board using ultrasonic device
Zbadano dwa wycinki z płyty o oznaczeniu "C" - wzorcowej i ze stwierdzonymi na przełomach delaminacjami. W obszarach delaminacji występowało obniżenie mierzonej prędkości fal ultradźwiękowych o co najmniej 15\% lub brak przejścia wiązki, co przedstawiono w sposób poglądowy przy pomocy czerwonej linii na rysunku 5 . $\mathrm{Na}$ podstawie badań 12 próbek płyt, w tym $3 \mathrm{z}$ wadami postawiono tezę, że stosując w/w metodę jest możliwe wykrycie delaminacji na obszarze średnicy wiązki ( $\varnothing 19$ $\mathrm{mm}$ ) metodą estymacji prędkości fali ultradźwiękowej jako średniej z 10 pomiarów punktowych.

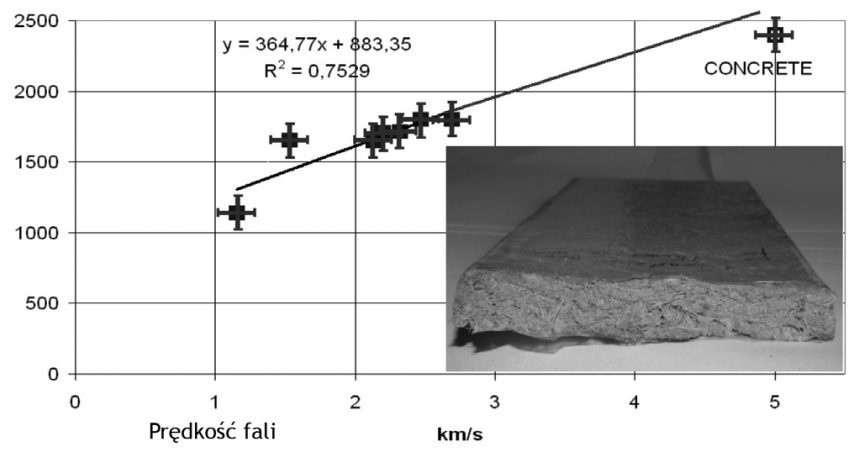

Rys. 4. Zależność prędkości fali ultradźwiękowej w funkcji gęstości objętościowej badanych płyt

Fig. 4. The dependence of ultrasonic wave velocity as a function of the bulk density of the tested boards
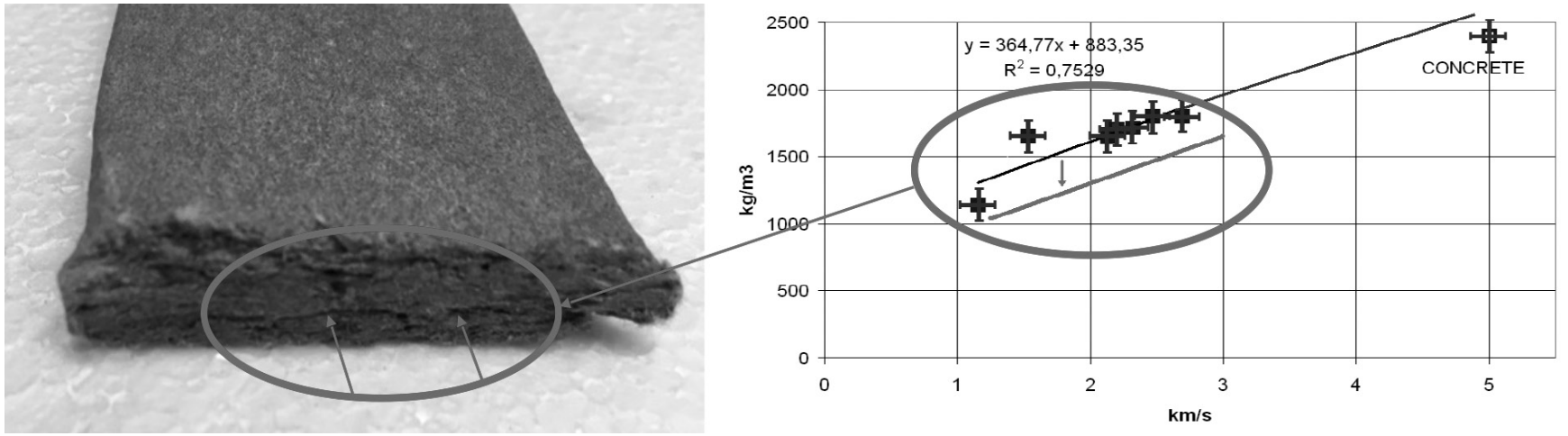

Rys. 5. Płyta włóknisto-cementowej z delaminacją wraz z wykresem zależności prędkości fali ultradźwiękowej w funkcji gęstości objętościowej badanych płyty bez delaminacji i z delaminacją (linia czerwona)

Fig. 5. Fiber-cement board with delamination along with a graph of ultrasonic wave velocity as a function of bulk density of respondents board without delamination and the delamination (red line)

\section{Podsumowanie}

W artykule przedstawiona została możliwość lokalizacji delaminacji w płycie włóknisto-cementowej za pomocą specjalnie do tego celu skonstruowanego urządzenia wykorzystującego metodę ultradźwiękową, ultradźwiękowe fale podłużne.

Proponowana metoda diagnostyczna umożliwia wykrywanie lokalnych nieciągłości, np. obszarów o obniżonej zwartości, czy delaminacji w płytach włóknisto-cementowych na obszarze średnicy wiązki metodą estymacji prędkości fali ultradźwiękowej. Zaletami metody są niewielkie wymiary urządzenia i krótki czas badania.

\section{Literatura}

[1] Informacje ze strony internetowej: http://www.euronit.de/

[2] Informacje ze strony internetowej: http://www.cembrit.com/

[3] PN-EN 12467:2013-03E - Płyty płaskie włóknisto-cementowe. Charakterystyka wyrobu i metody badań.

[4] Drelich R., Gorzelańczyk T., Pakuła M., Schabowicz K.: Automated Control of Cellulose Fibre Cement Boards with a Non-Contact Ultrasound Scanner, Automation in Construction, 57, s. 55-63, 2015.

[5] Gorzelańczyk T., Schabowicz K.: Non-Destructive Testing of Moisture in Cellulose Fiber Cement Boards, 11th European Conference on Non-Destructive Testing (ECNDT), Prague, 2014.

[6] Gorzelańczyk T., Schabowicz K.: Badania płyt włóknisto-cementowych zawierających materiały z recyklingu, Materiały Budowlane, nr 10, s. 27-29, 2015.
[7] Schabowicz K., Ranachowski Z., Jóźwiak-Niedźwiedzka D., Radzik Ł., Kudela Jr. S., Dvorak T.: Application of X-ray microtomography to quality assessment of fibre cement boards, Construction and Building Materials, Vol. 110, s. 182-188, 2016.

[8] Tomasz Gorzelańczyk, Krzysztof Schabowicz: Nieniszczące badania płyt włóknisto-cementowych metodą dielektryczną, Przegląd Spawalnictwa, 11/2014 s. 24-27.

[9] Jacek Szelążek: Próbki szklane grawerowane laserowo jako wzorce dwójłomności w badaniach ultradźwiękowych, Przegląd Spawalnictwa, 11/2014 s. 11-13. 